\title{
The potential of two vegetable-carried blood meals as protein sources in African catfish (Clarias gariepinus, Burchell) juvenile diets
}

\author{
Olukayode A. Makinde*, Emmanuel B. Sonaiya \\ Department of Animal Sciences, Obafemi Awolowo University, Ile-Ife, Nigeria; \\ *Corresponding Author: olukayodemakinde@yahoo.com
}

Received 21 September 2011; revised 29 November 2011; accepted 7 December 2011

\begin{abstract}
The study was designed to determine the growth response of African catfish (Clarias gariepinus) juveniles on diets with two vegetable-carried blood meals (brewers' dried grains with blood meal (BB) and rumen contents with blood meal (RB)) as protein sources and alternatives to imported commercial fish feed $\left(\mathrm{CatCo}^{\circledR}\right)$. Diets, with BB and RB included at $10 \%$, formulated to supply $45 \%$ crude protein and $4300 \mathrm{Kcal}$ digestible energy/kg in similarity with CatCo ${ }^{\circledR}$, were used in a 49-day trial in plastic tanks $(L \times B$ $\times \mathrm{H}: 53 \mathrm{~cm} \times 37 \mathrm{~cm} \times 29 \mathrm{~cm}$; capacity 50 liters). Juveniles were evaluated in terms of mean final body weight (MFBW), mean weight gain (MWG), average daily gain (ADG), specific growth rate (SGR), average daily feed intake (ADFI), feed conversion ratio (FCR), protein efficiency ratio (PER), feed cost/g gain (FCGA), and mortality (as $\%$ survival). CatCo ${ }^{\circledR}$ was superior $(P<0.05)$ to $B B$ and RB diets in supporting MFBW, MWG, ADG, FCR, SGR, ADFI and mortality. However, CatCo $^{\circledR}$ was similar $(P>0.05)$ to $B B$ in PER but inferior in FCGA (0.46 vs. $0.36 \mathrm{Naira} / \mathrm{g}$ gain; 1 US\$ $=N 150)$. RB was similar $(P>0.05)$ to $B B$ in $P E R$ but least economical in FCGA. The study demonstrated the potential of vegetable-carried blood meals from brewers' dried grains and dewatered rumen contents as alternatives for use as feed for African catfish especially juveniles.
\end{abstract}

Keywords: Blood Meal; Catfish Feed; Fishmeal Substitution; Rumen Contents

\section{INTRODUCTION}

The current global feed demands of the aquaculture sector rely almost exclusively on expensive fishmeal and fish oil. This portends sustainability of the sector due to dwindling fish stocks [1] that supply these resources. Ironically, aquaculture is one of the most rapidly increasing food production systems in the world [1,2]; therefore, the sustainability of the sector will require strategies not based mostly on capture fishery for feed.

The development of a more sustainable aquaculture feed production will depend on identifying and establishing alternative feedstuffs to fishmeal. The focus of research in this area is on use of vegetable or plant protein alternatives [1,3]. One of such potential feedstuffs is vegetable-carried blood meal [4], where crop residues or vegetable carriers (wheat offal, dewatered rumen contents, maize offal and brewers' dried grains) used as absorbents for blood were sun-dried and milled. Trials of these novel feedstuffs as replacement for expensive fishmeal in broiler chickens suggest a good potential alternative to fishmeal [5]. However, sun-dried rumen contents with blood meal and brewers' dried grains with blood meal (at $10 \%$ in diets with fishmeal, soybean meal, groundnut cake, vegetable oil, maize and wheat offal) were inferior in growth performance to a high quality commercial fish feed for African catfish fingerlings [6]. Nevertheless, feed cost/weight gain was better for brewers' dried grains with blood meal vs. commercial fish feed probably suggesting opportunity for improvement.

The inferior performance was probably due to higher fiber content in the blood meal diets for fingerlings. Robinson et al. (2001) [7] report the poor utilization of fibrous feed by catfish because cellulose is indigestible to catfish, and that starch digestion decreases as dietary level increases. However, the ability to utilize fiber by fish appears to increase with age and size although feed conversion efficiency decreases $[7,8]$ Therefore, the hypothesis is that juvenile African catfish may better utilize fiber than fingerlings and the objective was to determine the effect of sun-dried rumen contents and brewers' dried grains with blood meals on performance of juveniles. 


\section{MATERIALS AND METHODS}

\subsection{Experimental Procedure and Management of Catfish}

The experiment was carried out at the Wet Laboratory, of the Department of Animal Science, Faculty of Agriculture, Obafemi Awolowo University, Ile-Ife, Nigeria. Brewers' dried grains blood meal (BB) and rumen content blood meal (RB) produced as described by Makinde and Sonaiya (2010) [4] formed protein sources in formulating two diets. Briefly, blood was mixed twice to dewatered rumen content and brewers' dried grains at predetermined ratios and then sun-dried for 3 - $4 \mathrm{~h}$ before milling. These were included at levels of $10 \%$, supplying $45 \%$ crude protein and 4300 digestible energy $/ \mathrm{kg}$ in similarity with the commercial extruded and pelleted (2 $\mathrm{mm}$ ) fish feed (CatCo ${ }^{\circledR}$ Fish Concentrate, 45/12; Code: 4901420, Coppens International Bv., Helmond, Netherlands) purchased from a fish feed retailer (Table 1).

A locally fabricated pellet mill was used to pellet the blood meal diets through $2 \mathrm{~mm}$ die disc holes, sun-dried for $3 \mathrm{~h}$, and stored in sealed high-density polythene bags under ambient conditions. Seventy African catfish juveniles purchased from a commercial fish farm were acclimatized to experimental conditions for 10 days on the commercial fish feed twice a day $(07.00-08.00 \mathrm{~h}$ and $17.00-18.00 \mathrm{~h}$ ) at $5 \%$ of their body weight. From these 54 juveniles were randomly distributed into six plastic tanks ( $\mathrm{L} \times \mathrm{B} \times \mathrm{H}: 53 \mathrm{~cm} \times 37 \mathrm{~cm} \times 29 \mathrm{~cm}$; capacity 50 liters) at nine fish per tank. A table of random numbers aided the assignment of the three dietary treatments to the six plastic tanks (Steel and Torrie 1980) [9], and fish fed to satiation, twice a day, morning (07.00 - $08.00 \mathrm{~h})$ and evening (17.00 - $18.00 \mathrm{~h})$ for 49 days, at $5 \%$ of their body weight.

Water volume per tank remained at about half mark throughout with about three-quarters replenished every 2 days because of the absence of aerators and inability to use the tank's water flow-through device due to irregular water supply. Fish were weighed weekly and the amount of feed for each tank was adjusted according to mean body weights of the fish. No medication was given throughout. Diets were analyzed for proximate composition [10]. Physico-chemical parameters of water were monitored of weekly for dissolved oxygen (mg/L; APHA 1990) [11], hydrogen-ion concentration (pH meter; Denver Instruments $\mathrm{pH} /$ conductivity meter, model 7020), and water temperature $\left({ }^{\circ} \mathrm{C}\right.$; mercury-in-glass bulb thermometer). Live performance of juveniles were evaluated in terms of mean weight gain (MWG), average daily gain (ADG), specific growth rate (SGR), average daily feed intake (ADFI), feed conversion ratio (FCR), protein efficiency ratio (PER), feed cost/g gain (FCGA), and mortality (as \% survival).
Table 1. Ingredient and nutrient composition of catfish diets.

\begin{tabular}{|c|c|c|c|}
\hline \multirow{3}{*}{ Ingredients } & \multicolumn{3}{|c|}{ Diet (g/kg) } \\
\hline & $\mathrm{BB}^{1}$ & $\mathrm{RB}^{2}$ & $\mathrm{CatCo}^{\circledR 3}$ \\
\hline & \\
\hline Maize & 10 & 15 & NA \\
\hline Soyabean meal & 105 & 100 & NA \\
\hline Groundnut cake & 316.4 & 323 & NA \\
\hline Fishmeal & 300 & 300 & NA \\
\hline Wheat offal & 20 & 20 & NA \\
\hline BB2 & 100 & - & NA \\
\hline RB2 & - & 100 & NA \\
\hline Vegetable oil ${ }^{4}$ & 133.6 & 127 & NA \\
\hline Dicalcium phosphate & 11.5 & 11.5 & NA \\
\hline Salt & 1 & 1 & NA \\
\hline Vitamins and Mineral mix ${ }^{5}$ & 2.5 & 2.5 & NA \\
\hline Total & 1000 & 1000 & NA \\
\hline \multicolumn{4}{|l|}{ Calculated composition } \\
\hline $\mathrm{DE}, \mathrm{kcal} / \mathrm{kg}$ & 4300.46 & 4300.76 & 4300 \\
\hline Crude protein, \% & 45.28 & 45.83 & 45 \\
\hline Crude fiber, \% & 4.18 & 4.43 & 1.5 \\
\hline Crude fat, \% & 10.90 & 10.70 & 12 \\
\hline Ash, \% & 8.50 & 7.60 & 9.5 \\
\hline Nitrogen free extract, \% & 22.6 & 22.6 & 24 \\
\hline $\mathrm{Ca}, \%$ & 1.21 & 1.22 & NA \\
\hline P, \% & 0.72 & 0.75 & NA \\
\hline Lysine, \% & 2.23 & 2.92 & NA \\
\hline Methionine, \% & 0.82 & 0.86 & NA \\
\hline \multicolumn{4}{|l|}{ Analysed composition } \\
\hline Dry matter, \% & 91.45 & 91.16 & 92.7 \\
\hline Crude protein, \% & 34.41 & 33.25 & 46.41 \\
\hline Crude fiber, \% & 3.07 & 3.19 & 1.03 \\
\hline Crude fat, \% & 11.6 & 11.3 & 12.22 \\
\hline Ash, \% & 11.16 & 10.42 & 10.04 \\
\hline Nitrogen free extract, \% & 31.21 & 33 & 23 \\
\hline
\end{tabular}

${ }^{1} \mathrm{BB}=$ brewers' dried grains mixed with blood two times. ${ }^{2} \mathrm{RB}=$ rumen content mixed with blood two times. ${ }^{3} \mathrm{Cat} \mathrm{Co}^{\circledR}$ concentrate is a complete fish feed, Code: 4901420 (45/12), made by Coppens International Bv., Helmond, Netherlands. Ingredient composition not supplied by manufacturer, only nutrient composition. NA $=$ Not Available. ${ }^{4}$ Soya bean oil. ${ }^{5}$ Provided the following (per kg diet): Vitamin A, 12,500 IU; Vitamin D, 2500 IU; Vitamin E, 40 mg; Vitamin K, 2 mg; Vitamin B1, 3 mg; Vitamin B2, 5.5 mg; Niacin $55 \mathrm{mg}$; Calcium pantothenate, $11.5 \mathrm{mg}$; Vitamin B 6, $5 \mathrm{mg}$; Vitamin B 12, 0.025 mg; Choline chloride, $500 \mathrm{mg}$; Folic acid, $1 \mathrm{mg}$; Biotin, $0.08 \mathrm{mg}$; Manganese, $120 \mathrm{mg}$; Iron, $100 \mathrm{mg}$; Zinc, $80 \mathrm{mg}$; Copper, $8.5 \mathrm{mg}$; Iodine, $1.5 \mathrm{mg}$; Cobalt, $0.3 \mathrm{mg}$; Selenium, $0.12 \mathrm{mg}$; Anti-oxidant, $120 \mathrm{mg}$.

\subsection{Statistical Analysis}

The differences in growth performance and water quality between the three diets were analyzed with the 2way analysis of variance using the General Linear Models procedure of SAS (2000) [12]. The data was treated as a completely randomized design with diets as the main treatment effect and replicates as another factor. The replicate was considered as another factor in order to increase the sensitivity of the experiment by reducing the residual error. The model used was:

$\mathrm{Y}$ ijk $=\mu+\mathrm{Bi}+\mathrm{Rj}+\varepsilon \mathrm{ijk}$; where: $\mathrm{Y}$ ijk = growth performance and water quality parameters, $\mu=$ overall mean, $\mathrm{Bi}=$ diet effect, $\mathrm{Rj}=$ replicate effect and $\varepsilon \mathrm{ijk}=$ residual error. 
Differences between the blends were resolved by Duncan's multiple range test of the SAS (2000) [11] statistical package. Statistical significance was established when probability was less than $5 \%$ level of significance.

\section{RESULTS AND DISCUSSION}

Table 2 presents the live performance of catfish juveniles fed the three different diets. There were no significant differences $(\mathrm{P}>0.05)$ between diets in water quality parameters of $\mathrm{pH}$, dissolved oxygen and water temperature signifying that the rearing conditions were similar. Summerfelt (1998) [13] and Santhosh and Selvaraj (2005) [14] indicate that sub-optimum water quality parameters, especially dissolved oxygen, $\mathrm{pH}$ and water temperature negatively affects growth performance of catfish. Fish fed blood meal had higher mortality (survival\%) than those on CatCo ${ }^{\circledR}$ probably due to the quality of the feed since post mortem did not reveal any specific cause. CatCo ${ }^{\circledR}$ is manufactured from very high quality fishmeal and fish oil [15].

The mean final body weight (MFBW), mean weight gain (MWG), average daily gain (ADG), average daily feed intake (ADFI), specific growth rate (SGR), and average daily protein intake (ADPI) were highest $(\mathrm{P}<0.05)$ for fish fed CatCo ${ }^{\circledR}$ followed by BB2 and RB2 diets. In spite of these, the MFBW for catfish on $\mathrm{BB}$ and $\mathrm{RB}$ were just about $30 \%$ less than for CatCo ${ }^{\circledR}$ probably indicating fair protein utilization. Fundamental nutritional differences between the diets were probably responsible for the superior performance in these parameters for juveniles fed $\mathrm{CatCo}^{\circledR}$ compared to those fed BB2 or RB2 diets.

For example, the vegetable-carried blood meal diets were not extruded and chemically analyzed CP contents fell short of the calculated compared to $\mathrm{CatCo}^{\circledR}$ (Table 1) and this probably resulted from the quality and type of ingredients used. Usually, high quality or purified ingredients are used when diets with high nutrient density and content with almost $100 \%$ bioavailability are desired (NRC 1993) [9] as found in CatCo ${ }^{\circledR}$ (Coppens 2005) [15]. These results were similar to those obtained for fingerlings fed similar diets by Makinde et al. (2007) [6] indicating lack of superiority in performance due to age or size.

The $\mathrm{BB}$ diet was more economical than $\mathrm{CatCo}^{\circledR}$ and $\mathrm{RB}$ diets in terms of feed cost/g gain (FCGA) and this was similar to results obtained for fingerlings by Makinde et al. (2007) [6]. The advantage of the commercial feed (CatCo ${ }^{\circledR}$ ) might be apparent since BB was less in the cost per unit weight gain. The reduced productivity may be offset by the reduced costs. Further, juveniles fed Cat- $\mathrm{Co}^{\circledR}$ did not use protein more efficiently than BB but RB, as protein efficiency ratio (PER) for CatCo ${ }^{\circledR}$ was not superior $(\mathrm{P}>0.05)$ to $\mathrm{BB}$, which was similar to $\mathrm{RB}$ ( $\mathrm{P}>0.05$ ). However, Makinde et al. (2007) [6] found fingerlings fed $\mathrm{BB}$ and $\mathrm{RB}$ diets inferior to $\mathrm{CatCo}^{\circledR}$ in PER and this probably suggests that juveniles were more stable in the efficiency of protein utilization than fingerlings despite that feed conversion efficiency decreases with age in catfish (Robinson et al. 2001) [7]. Although, the expectation was not that juveniles on the blood meal diets will be superior to those on $\mathrm{CatCo}^{\circledR}$ because of

Table 2. Live performance and water quality of catfish juveniles fed commercial fish feed, brewers' dried grains blood meal and rumen content blood meal diets.

\begin{tabular}{|c|c|c|c|c|c|}
\hline \multirow[b]{2}{*}{ Parameters } & \multicolumn{3}{|c|}{ Diet } & \multirow[b]{2}{*}{$\mathrm{SEM}^{4}$} & \multirow[b]{2}{*}{ P Value } \\
\hline & $\mathrm{BB}^{1}$ & $\mathrm{RB}^{2}$ & $\mathrm{CatCo}^{\mathbb{B}_{3}}$ & & \\
\hline Mean initial body weight (g/fish) & 20.64 & 20.86 & 20.58 & 0.1 & \\
\hline Mean final body weight (g/fish) & $28.82^{\mathrm{b}}$ & $27.00^{\mathrm{b}}$ & $39.78^{\mathrm{a}}$ & 2.65 & $<0.0001$ \\
\hline Mean weight gain (g/fish) & $8.18^{\mathrm{b}}$ & $6.16^{\mathrm{b}}$ & $19.12^{\mathrm{a}}$ & 2.65 & $<0.0001$ \\
\hline Average daily gain (g/fish) & $0.17^{\mathrm{b}}$ & $0.13^{\mathrm{b}}$ & $0.39^{\mathrm{a}}$ & 0.05 & $<0.0001$ \\
\hline Average daily feed intake (g/fish) & $0.39^{\mathrm{b}}$ & $0.41^{\mathrm{b}}$ & $0.60^{\mathrm{a}}$ & 0.05 & $<0.0001$ \\
\hline Feed conversion ratio (g feed/g gain) & $2.34^{\mathrm{b}}$ & $3.41^{\mathrm{a}}$ & $1.54^{\mathrm{c}}$ & 0.38 & $<0.0001$ \\
\hline Specific growth rate (\%/day) & $0.69^{\mathrm{b}}$ & $0.53^{\mathrm{b}}$ & $1.35^{\mathrm{a}}$ & 0.16 & $<0.0001$ \\
\hline Protein efficiency ratio (g gain/g protein intake) & $1.27^{\mathrm{ab}}$ & $1.12^{\mathrm{b}}$ & $1.42^{\mathrm{a}}$ & 0.11 & 0.0038 \\
\hline Feed cost $(\mathrm{N}) /$ g gain $^{5}$ & 0.36 & 0.51 & 0.46 & 0.04 & \\
\hline Survival (\%) & $77.78^{\mathrm{b}}$ & $73.30^{\mathrm{b}}$ & $100^{\mathrm{a}}$ & 6.88 & 0.02 \\
\hline \multicolumn{6}{|l|}{ Water quality } \\
\hline $\mathrm{pH}$ & 6.95 & 6.96 & 7.01 & 0.02 & 0.07 \\
\hline Dissolved oxygen (mg/l) & 4.79 & 4.84 & 4.81 & 0.01 & 0.35 \\
\hline Water temperature $\left({ }^{\circ} \mathrm{C}\right)$ & 26.7 & 26.76 & 26.8 & 0.02 & 0.29 \\
\hline
\end{tabular}

${ }^{\mathrm{abc}}$ Means on the same row with the same superscripts are not significantly different $(\mathrm{P}>0.05)$; ${ }^{1} \mathrm{BB} 2=$ brewers' dried grains mixed with blood two times and sun-dried; ${ }^{2} \mathrm{RB} 2=$ rumen content mixed with blood two times and sun-dried; ${ }^{3} \mathrm{Cat} C 0^{\circledR}$ concentrate is a complete fish feed, Code: 4901420 (45/12), made by Coppens International Bv., Helmond, Netherlands; ${ }^{4} \mathrm{SEM}=$ standard error of means; ${ }^{5} 1$ US\$ = N150. 
disparity in the quality of the ingredients, the comparison was necessary to evaluate the efficiency of fish feed made from locally available and underutilized ingredients. CatCo ${ }^{\circledR}$ is high quality fish feed, which is extruded, imported, expensive and may not always be available. In contrast, the vegetable-carried blood meal diets used common feed ingredients and simply produced. These results indicate good potential for the vegetable-carried blood meals in catfish diets probably with improvement in nutritive value such as use of exogenous enzymes (e.g. xylanases, phytases, cellulases and proteases) on the crude fiber and protein components.

\section{CONCLUSION}

Vegetable-carried blood meals from brewers' dried grains and dewatered rumen contents provide potential alternatives for use as feed for African catfish especially juveniles. Improvement in the quality of vegetable-carried blood meal through chemical, physical or biological measures may contribute to potential as alternatives to expensive high quality fish feed based on fishmeal and fish oil.

\section{ACKNOWLEDGEMENTS}

Raw Materials Research and Development Council (RMRDC), Abuja, Nigeria provided funding for the research reported in this article. Mr J. O. S. Adeyeye and the workers at the Araromi Abattoir, Ile-Ife, Osun State, Nigeria are also appreciated for their cooperation and assistance.

\section{REFERENCES}

[1] Koeleman, E. (2009) Aquaculture takes environment seriously. Feed Tech, 13.

http://www.allaboutfeed.net/background/aquaculture-take s-environment-seriously-11488.html

[2] Delgado, C.L., Wada, N., Rosegrant, M.W., Meijer, S. and Ahmed, M. (2003) The future of fish: Issues and trends to 2020. International Food Policy Research Institute (IFPRI) and the WorldFish Center. http://www.ifpri.org/pubs/ib/ib15.pdf

[3] Otubusin S.O., Ogunleye, F.O. and Agbebi, O.T. (2009) Feeding trials using local protein sources to replace fishmeal in pelleted feeds in catfish (Clarias gariepinus Burchell 1822) culture. European Journal of Scientific Research, 31, 142-147.
[4] Makinde, O.A. and Sonaiya, E.B. (2010) A simple technology for production of vegetable-carried blood or rumen fluid meals from abattoir wastes. Animal Feed Science and Technology, 162, 12-19. doi:10.1016/j.anifeedsci.2010.08.011

[5] Makinde, O.A., Sonaiya, E.B. and Adeyeye, J.O.S. (2008) Conversion of abattoir wastes into livestock feed: Chemical composition of sun-dried rumen content with blood meal and its effect on performance of broiler chickens. Tropentag 2008-Conference on International Research on Food Security, Natural Resource Management and Rural Development, University of Hohenheim, Stuttgart, 7-9 October 2008. http://www.tropentag.de/2008/abstracts/full/726.pdf

[6] Makinde, O.A., Sonaiya, E.B. and Adeyeye, J.O.S. (2007) Performance of African catfish, Clarias gariepinus (Burchell) fingerlings on diets with two vegetable-carried blood meals compared with a commercial fish feed. Tropical Journal of Animal Science, 10, 135-140.

[7] Robinson, E.H., Li, M.H. and Manning, B.B. (2001) A practical guide to nutrition, feeds, and feeding of channel catfish (second revision). Mississipi Agricultural and Forestry Experimental Station Bulletin 1113, Office of Agricultural Communications, Mississipi.

[8] Steel, R.G.D. and Torrie, J.H. (1980) Principles and procedures of statistics. McGraw Hill Co., New York.

[9] NRC (1993) Nutrient requirements of fish. Committee on Animal Nutrition, Board on Agricultural National R.C. Academy Press, Washington DC.

[10] AOAC (1990) Asssociation of official analytical chemists. Official Methods of Analysis, 15th Edition, AOAC, Arlington Virginia, USA.

[11] American Public Health Association (APHA) (1990) Standard methods of examination of water and waste water. Washington DC, 1134-1135.

[12] Statistical Analysis Systems (SAS) (2000) Guide for personal computers. Release 8.1. SAS institute Inc., Cary, NC, USA.

[13] Summerfelt, R.C. (1998) Water quality considerations for aquaculture. http://www.aquanic.org/publicat/state/il-in/ces/summerfl. pdf

[14] Santhosh, K. and Selvaraj, S. (2005) African catfish: A potential candidate species for urban/periurban aquaculture in India. Aquaculture Asia, 10, 11-12. http://www.enaca.org

[15] Coppens (2005) Coppens feed for aquaculture. CatCo ${ }^{\circledR}$ grower 12-EF. Coppens International Bv., Helmond, Netherlands. http://www.coppens-int.com 